Florida International University

FIU Digital Commons

Biomolecular Sciences Institute: Faculty

Publications

College of Arts, Sciences \& Education

$11-5-2019$

\title{
Kinetic Study of DNA Topoisomerases by Supercoiling-Dependent Fluorescence Quenching
}

\author{
Yunke Wang \\ Biomolecular Sciences Institute, Department of Chemistry \& Biochemistry, and Enviromental and \\ Occupational Health, Robert Stempel College of Public Health \& Social Work, Florida International \\ University, yunkwang@fiu.edu \\ Samantha Rakela \\ Biomolecular Sciences Institute, Department of Chemistry \& Biochemistry, and Enviromental and \\ Occupational Health, Robert Stempel College of Public Health \& Social Work, Florida International \\ University \\ Jeremy W. Chambers \\ Biomolecular Sciences Institute, Department of Chemistry \& Biochemistry, and Enviromental and \\ Occupational Health, Robert Stempel College of Public Health \& Social Work, Florida International \\ University \\ Zi-Chun Hua \\ School of Life Sciences, Nanjing University \\ Mark T. Muller \\ TopoGEN, Inc.

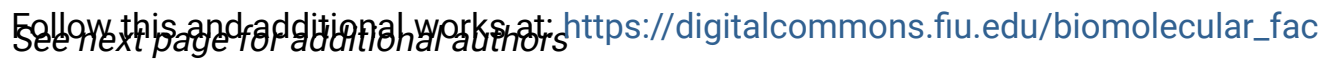

\section{Recommended Citation}

Wang Y, Rakela S, Chambers JW, Hua ZC, Muller MT, Nitiss JL, Tse-Dinh YC, Leng F. Kinetic Study of DNA Topoisomerases by Supercoiling-Dependent Fluorescence Quenching. ACS Omega. 2019 Oct 24;4(19):18413-18422. doi: 10.1021/acsomega.9b02676. PMID: 31720544; PMCID: PMC6844113.

This work is brought to you for free and open access by the College of Arts, Sciences \& Education at FIU Digital Commons. It has been accepted for inclusion in Biomolecular Sciences Institute: Faculty Publications by an authorized administrator of FIU Digital Commons. For more information, please contact dcc@fiu.edu. 


\section{Authors}

Yunke Wang, Samantha Rakela, Jeremy W. Chambers, Zi-Chun Hua, Mark T. Muller, John L. Nitiss, YukChing Tse-Dinh, and Fenfei Leng 


\section{Kinetic Study of DNA Topoisomerases by Supercoiling-Dependent Fluorescence Quenching}

Yunke Wang, ${ }^{\dagger, \ddagger}$, Samantha Rakela, ${ }^{\dagger, \ddagger}$ Jeremy W. Chambers, ${ }^{\dagger, \|}$ Zi-Chun Hua, ${ }^{\S, \perp}$ Mark T. Muller, ${ }^{\#}$

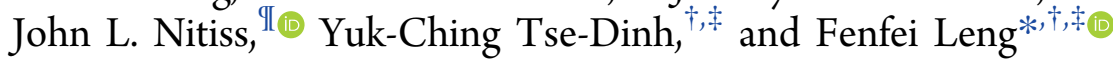

${ }^{\dagger}$ Biomolecular Sciences Institute, ${ }^{\star}$ Department of Chemistry \& Biochemistry, and "Enviromental and Occupational Health, Robert Stempel College of Public Health \& Social Work, Florida International University, Miami, Florida 33199, United States

${ }^{\S}$ School of Life Sciences, Nanjing University, Nanjing, Jiangsu Province 210023, P. R. China

${ }^{\perp}$ Changzhou High-Tech Research Institute of Nanjing University and Jiangsu TargetPharma Laboratories Inc., Changzhou, Jiangsu 213164, P. R. China

\#TopoGEN, Inc., Buena Vista, Colorado 81211, United States

II Pharmaceutical Sciences Department, College of Pharmacy at Rockford, University of Illinois at Chicago, 1601 Parkview Avenue, N310, Rockford, Illinois 61107, United States

\section{Supporting Information}

ABSTRACT: DNA topoisomerases are essential enzymes for all living organisms and important targets for anticancer drugs and antibiotics. Although DNA topoisomerases have been studied extensively, steady-state kinetics has not been systematically investigated because of the lack of an appropriate assay. Previously, we demonstrated that newly synthesized, fluorescently labeled plasmids pAB1_FL905 and pAB1_FL924 can be used to study DNA topoisomerase-catalyzed reactions by fluorescence resonance energy transfer (FRET) or supercoiling-dependent fluorescence quenching (SDFQ). With the FRET or SDFQ method, we performed steady-state kinetic studies for six different DNA topoisomerases including two type IA enzymes (Escherichia coli and Mycobacterium smegmatis

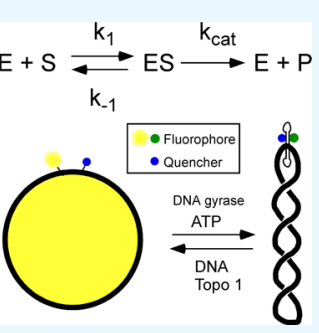
DNA topoisomerase I), two type IB enzymes (human and variola DNA topoisomerase I), and two type IIA enzymes (E. coli DNA gyrase and human DNA topoisomerase II $\alpha$ ). Our results show that all DNA topoisomerases follow the classical Michaelis-Menten kinetics and have unique steady-state kinetic parameters, $K_{\mathrm{M}}, V_{\max }$, and $k_{\text {cat }}$. We found that $k_{\text {cat }}$ for all topoisomerases are rather low and that such low values may stem from the tight binding of topoisomerases to DNA. Additionally, we confirmed that novobiocin is a competitive inhibitor for adenosine $5^{\prime}$-triphosphate binding to E. coli DNA gyrase, demonstrating the utility of our assay for studying topoisomerase inhibitors.

\section{INTRODUCTION}

DNA topoisomerases are enzymes that catalyze DNA structural alterations that include relaxation of positively and negatively supercoiled DNA and resolution of DNA knots and catenanes. ${ }^{1-4}$ These enzymes create transient DNA breaks to catalyze these changes in DNA topology. ${ }^{1-4}$ Because topological issues are intrinsic to double-stranded DNA, DNA topoisomerases are critical for DNA replication, transcription, recombination, and maintenance of the chromosome structure. ${ }^{7-9}$ DNA topoisomerases are important targets for anti-bacterial agents as well as anti-cancer drugs. ${ }^{10,11}$ Human topoisomerases I and II are targets of clinically important anticancer drugs, such as topotecan ${ }^{10,12}$ and doxorubicin. ${ }^{10}$ Bacterial DNA gyrase and Topo IV (another type II enzyme) are the targets of fluoroquinolones, such as ciprofloxacin, which are critically important antibiotics. ${ }^{13-15}$ Bacterial topoisomerases continue to be useful targets for the discovery of novel antibacterial drugs that could avoid cross resistance with current antibiotics to counter the serious global health problem of multidrug-resistant bacterial pathogens.

DNA topoisomerases are classified into type I and II families according to whether they make a transient single-stranded nick or double-stranded break during catalysis. ${ }^{1}$ Each family is further divided into different subfamilies depending on catalytic mechanisms. ${ }^{1,4}$ Type I enzymes cleave only one strand of the DNA templates, while type II enzymes transiently cleave both strands. During catalysis, type IA DNA topoisomerases (bacterial DNA topoisomerases I and III) link to the 5 '-phosphate. In contrast, type IB topoisomerases (human topoisomerase I and poxvirus DNA topoisomerase I) link to the $3^{\prime}$-phosphate of DNA., Although most DNA topoisomerases can relax (-) and/or (+) DNA supercoiling, ${ }^{1,4}$ bacterial DNA gyrase is the only enzyme that can actively introduce (-) DNA supercoiling to its DNA substrates. ${ }^{1,4}$

One major assay for DNA topoisomerase activity is gel electrophoresis. ${ }^{16,17}$ Although gel electrophoresis is quick and convenient for resolving topoisomers of closed circular plasmid DNA molecules, ${ }^{16,17}$ it is less suitable for probing kinetics because gel electrophoresis cannot readily provide quantitative analysis of DNA supercoiling in real time. More recently,

Received: August 19, 2019

Accepted: October 11, 2019

Published: October 24, 2019 
single-molecule techniques, such as magnetic tweezers, have been used to analyze mechanisms of DNA topoisomerasescatalyzed supercoiling/relaxation reactions. ${ }^{18-21}$ Indeed, these elegant techniques provided mechanistic insights into various DNA topoisomerase-catalyzed supercoiling/relaxation reactions; ${ }^{22-29}$ however, DNA molecules must be physically linked onto solid surfaces. ${ }^{18,30}$ It is also not straightforward to derive steady-state kinetic parameters, such as $K_{\mathrm{M}}$ and $k_{\text {cat }}$ from these studies. Additionally, constraint onto magnetic beads could influence diffusion or other aspects of radial DNA access of a topoisomerase before, during, or after the breaking/resealing reaction. $^{18,30}$

Recently, we synthesized a type of unique fluorescently labeled DNA molecules that can be used to study DNA topoisomerases by fluorescence resonance energy transfer (FRET) or supercoiling-dependent fluorescence quenching (SDFQ). ${ }^{31}$ This SDFQ method stems from the fact that alternating adenine-thymine sequences $(\mathrm{AT})_{n}$ in the closed circular plasmids undergo very rapid cruciform formation/ deformation depending on the supercoiling density of the plasmids. ${ }^{32,33}$ A pair of fluorophore-quencher were inserted in the $(\mathrm{AT})_{n}$ sequence, so that the distance between the fluorophore and quencher is dramatically changed when the plasmids adopt supercoiled (sc) or relaxed (rx) status. ${ }^{31}$ As a result, the fluorescence intensity of the plasmids is also greatly changed upon supercoiling transition. ${ }^{31}$ We demonstrated that these DNA molecules are excellent tools to examine relaxation/supercoiling kinetics of DNA topoisomerases and can be configured into rapid and efficient high-throughput screening assays to identify topoisomerase inhibitors. ${ }^{31}$ In this work, we report an improved procedure to rapidly and efficiently synthesize and purify fluorescently labeled plasmid DNA molecules. Using the SDFQ assays, we find that all 6 DNA topoisomerases examined show characteristics of classical Michaelis-Menten kinetics. We also demonstrate that novobiocin is a competitive inhibitor for adenosine 5'triphosphate (ATP) binding to Escherichia coli DNA gyrase.

\section{MATERIALS AND METHODS}

Materials. Restriction enzyme Nt.BbvCI, T4 DNA polymerase, T5 exonuclease, and T4 DNA ligase were purchased from New England Biolabs (Beverly, MA, USA). E. coli DNA topoisomerase I, E. coli DNA gyrase, Mycobacterium smegmatis DNA topoisomerase I, variola DNA topoisomerase I, human topoisomerase I, and human topoisomerase II $\alpha$ were purified as described previously. ${ }^{34-37}$ Ethidium bromide, buffer-saturated phenol, and isopropanol were purchased from Thermo Fisher Scientific, Inc. The synthetic oligonucleotides FL905 and FL924 were purchased from MWG-Biotech, Inc. (Huntsville, AL) and were described previously. ${ }^{31}$ Plasmid pAB1 was described previously ${ }^{31}$ and purified using commercial plasmid purification kits obtained from QIAGEN, Inc. (Valencia, CA).

Synthesis of rx and sC pAB1_FL905 and pAB1_FL924. The preparation of rx and sc pAB1_FL905 and pAB1_FL924 was described previously ${ }^{31}$ with some modifications. Briefly, 1 $\mathrm{mg}$ of pAB1 ( $\sim 570 \mathrm{pmol})$ was digested by 2500 units of $\mathrm{Nt}$.BbvCI in $20 \mathrm{~mL}$ of $1 \times$ CutSmart buffer for $1 \mathrm{~h}$ at $37^{\circ} \mathrm{C}$. After the digestion, 8000 pmol of phosphorylated FL905 or FL924 was added into the reaction mixture. The reaction mixture was incubated at $90{ }^{\circ} \mathrm{C}$ in a $4 \mathrm{~L}$ water bath for 2 min and then cooled down to room temperature in the water bath ( 4-5 h; usually this step was carried out overnight). To generate rx pAB1_FL905 or pAB1_FL924, 25000 units of T4 DNA ligase were added in the presence of $10 \mathrm{mM}$ of dithiothreitol (DTT) and $2 \mathrm{mM}$ of ATP (final concentrations). The reaction mixtures were incubated at $37{ }^{\circ} \mathrm{C}$ for $60 \mathrm{~min}$ to seal the nicks, thereby yielding the rx pAB1 FL905 or pAB1_FL924. T4 DNA polymerase (750 units) and dNTPs $(100 \mu \mathrm{M})$ were added to the ligation mixture to increase the yield of the rx pAB1_FL905 or pAB1_FL924. After the ligation step, 5000 units of T5 exonuclease were added into the reaction mixture at $37^{\circ} \mathrm{C}$ for $60 \mathrm{~min}$ to digest the nicked pAB1 and oligomer FL905 or FL924. The rx pAB1_FL905 or pAB1_FL924 sample was extracted with $20 \mathrm{~mL}$ of phenol, precipitated with isopropanol, washed once with $70 \%$ ethanol, and dialyzed against a large excess of $1 \times \mathrm{TE}$ buffer solution (10 $\mathrm{mM}$ Tris- $\mathrm{HCl}, 1 \mathrm{mM}$ ethylenediaminetetraacetic acid (EDTA), pH 8.0). To generate sc pAB1_FL905 or pAB1_FL924, the ligation reaction was carried out in the presence of $25 \mu \mathrm{M}$ of ethidium bromide (EB). The other steps are the same as the synthesis of $\mathrm{rx}$ pAB1 FL905 or pAB1_FL924. The sc pAB1_FL905 or pAB1_FL924 sample was extracted with $20 \mathrm{~mL}$ of phenol, precipitated with isopropanol, washed once with $70 \%$ ethanol, and dialyzed against a large excess of $1 \times$ TE buffer solution.

Fluorescence Spectroscopy. Fluorescence measurements were performed using a Horiba FluoroMax-3 spectrofluorimeter with an excitation wavelength of $494 \mathrm{~nm}$ or a Biotek Synergy H1 Hybrid Plate Reader with an excitation wavelength of $482 \mathrm{~nm}$ where plasmid pAB1_FL905 was used. Alternatively, fluorescence measurements were performed using a homemade spectrofluorimeter with a $532 \mathrm{~nm}$ laser for the excitation light source where pAB1_FL924 was used due to the fact that the fluorophore TAMRA of pAB1_FL924 was stable under this condition.

DNA Supercoiling Density Determination. Sc pAB1_FL924 $(4.6 \mu \mathrm{g})$ was relaxed by variola DNA topoisomerase $\mathrm{I}$ in the presence of various concentrations of $\mathrm{EB}$ at $37^{\circ} \mathrm{C}$ in $1 \times$ CutSmart buffer for $1 \mathrm{~h}$. Subsequently, the relaxation reaction was stopped by addition of an equal volume of phenol. The reaction mixtures were extracted one more time with phenol (a total of 2 times of phenol extraction) and dialyzed against $1 \mathrm{~L}$ of $10 \mathrm{mM}$ Tris- $\mathrm{HCl}, \mathrm{pH} 8.0$ twice overnight. The topological status of each DNA sample was analyzed by electrophoresis in a $1 \%$ agarose gel in $1 \times$ TAE buffer [40 mM Tris-acetate ( $\mathrm{pH} 7.8)$ and $1 \mathrm{mM}$ EDTA] containing different concentrations of chloroquine. After electrophoresis, agarose gels were stained with $\mathrm{EB}$, destained, and photographed under UV light. The DNA linking number change $(\Delta \mathrm{Lk})$ was determined by analyzing the distributions of the topoisomers, and the supercoiling density $(\sigma)$ was calculated as follows

$$
\sigma=\frac{\Delta \mathrm{Lk}}{\mathrm{Lk}^{0}}=\frac{\mathrm{Lk}-\mathrm{Lk}^{0}}{\mathrm{Lk}^{0}}
$$

where $\mathrm{Lk}^{0}$ and $\mathrm{Lk}$ represent the DNA linking number for the relaxed and the supercoiled DNA, respectively.

The fluorescence intensity of these DNA samples was measured by using a microplate reader with $\lambda_{\mathrm{ex}}=550 \mathrm{~nm}$ and $\lambda_{\mathrm{em}}=580 \mathrm{~nm}$. DNA concentration was determined by UV absorbance at $260 \mathrm{~nm}$ using a Cary 50 spectrophotometer.

Steady-State Kinetic Measurements. All steady-state kinetic measurements were performed in $60 \mu \mathrm{L}$ of a buffer solution containing either sc pAB1_FL905 (pAB1_FL924) or rx pAB1_FL905 (pAB1_FL924). $\bar{C}$ utSmart buffer $[1 \times$ is 50 
$\mathrm{mM}$ KAc, $20 \mathrm{mM}$ Tris-Ac, $10 \mathrm{mM} \mathrm{Mg}(\mathrm{AC})_{2}, 100 \mu \mathrm{g} / \mathrm{mL}$ bovine serum albumin (BSA), $\mathrm{pH}$ 7.9] was used for E. coli DNA topoisomerase I, M. smegmatis DNA topoisomerase I, and variola DNA topoisomerase I. Human Top 1 buffer $(1 \times$ is $10 \mathrm{mM}$ Tris-Cl, $\mathrm{pH} 7.9,150 \mathrm{mM} \mathrm{NaCl}, 0.1 \%$ BSA, $0.1 \mathrm{mM}$ spermidine, $5 \%$ glycerol) was used for human DNA topoisomerase I. Human Top2 buffer $(1 \times$ is $50 \mathrm{mM}$ Tri$\mathrm{HCl}, \mathrm{pH}$ 8, $100 \mathrm{mM} \mathrm{KCl}, 1 \mathrm{mM}$ EDTA, $8 \mathrm{mM} \mathrm{MgCl}_{2}, 35 \mathrm{mM}$ $\beta$-mercaptoethanol, $0.5 \mathrm{mg} / \mathrm{mL} \mathrm{BSA}$, and $2 \mathrm{mM} \mathrm{ATP}$ or indicated in the assay) was used for human DNA topoisomerase II. DNA gyrase buffer $(1 \times$ is $35 \mathrm{mM}$ Tris- $\mathrm{HCl}, \mathrm{pH} 7.5,24$ $\mathrm{mM} \mathrm{KCl}, 4 \mathrm{mM} \mathrm{MgCl}_{2}, 2 \mathrm{mM}$ DTT, $5 \mathrm{mM}$ spermidine, 0.1 $\mathrm{mg} / \mathrm{mL} \mathrm{BSA}, 6.5 \%$ glycerol, and $1.75 \mathrm{mM}$ ATP or indicated in the assay) was used for E. coli DNA gyrase. Kinetic reaction mixtures were assembled on ice (without enzyme) and equilibrated to $37{ }^{\circ} \mathrm{C}$ usually for $5 \mathrm{~min}$ (in a cuvette inside the spectrofluorimeter). Then, one of DNA topoisomerases was added directly to the cuvette and mixed with other components of reaction mixtures by pipetting three times. The fluorescence intensities of the reaction mixture at $521 \mathrm{~nm}$ (for pAB1_FL905) or at $582 \mathrm{~nm}$ (for pAB1_FL924) were recorded every $\overline{5}$. The initial velocity of the reactions was calculated from linear-fitting of the first 5-10 data points. The steadystate kinetic parameters $K_{\mathrm{M}}, V_{\text {max }}$ and $k_{\text {cat }}$ were obtained by fitting the Michaelis-Menten equation

$$
\begin{aligned}
& V_{0}=V_{\max } \frac{[\mathrm{S}]}{K_{\mathrm{M}}+[\mathrm{S}]} \\
& k_{\text {cat }}=\frac{V_{\max }}{[\mathrm{E}]}
\end{aligned}
$$

where $V_{0},[\mathrm{~S}], K_{\mathrm{M}}, V_{\max },[\mathrm{E}]$, and $k_{\mathrm{cat}}$ represent the initial velocity, substrate concentration, Michaelis constant, maximum velocity, enzyme concentration, and turn-over number, respectively.

\section{RESULTS AND DISCUSSION}

$A$ rapid and efficient procedure to synthesize and purify fluorescently labeled plasmid DNA molecules. Recently, we reported the synthesis of a type of unique fluorescently labeled plasmid DNA molecules that can be used to study DNA topology and topoisomerases by FRET or SDFQ. ${ }^{31}$ Although the synthesis yield of the fluorescently labeled plasmid DNA molecules was high, agarose gel electrophoresis or $\mathrm{CsCl}-\mathrm{EB}$ ultracentrifugation banding had to be used to purify the labeled products from unlabeled nicked DNA, the oligomer, and ATP. ${ }^{31}$ Both purification methods have unavoidable disadvantages. Specifically, gels are not suited for purifying mg quantities of plasmid DNA, and although $\mathrm{CsCl}-\mathrm{EB}$ ultracentrifugation banding is capable of purifying the labeled products in the milligram range, it is a lengthy, expensive, and labor-intensive procedure. Additionally, $\sim 20 \%$ products may be lost during this purification procedure and handling circular DNA in the presence of EB causes significant nicking of the substrate DNA. Therefore, it was desirable to develop a method to avoid these two laborintensive purification methods. We developed a simple and efficient procedure to synthesize and purify fluorescently labeled rx and sc plasmid DNA molecules (Figure 1). We used T5 exonuclease to digest nicked and gapped plasmids, and also oligomers FL905 and FL924 because T5 exonuclease cannot digest either rx and sc plasmid DNA molecules ${ }^{38}$ (compare

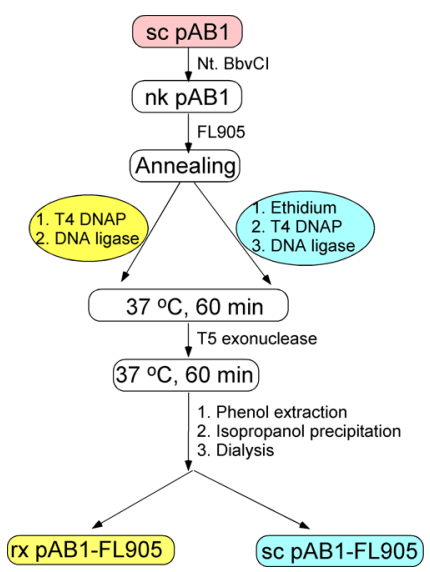

Figure 1. Rapid and efficient procedure to produce $\mathrm{rx}$ or $\mathrm{sc}$ fluorescently labeled plasmid pAB1 FL905. The experimental procedure was described under the Materials and Methods. Abbreviations: T4 DNAP, T4 DNA polymerase; DNA ligase, T4 DNA ligase; sc, supercoiled; nk, nicked, rx, relaxed.

lanes 1 and 2 with lane 4, and also lanes 5 and 6 with lane 8 of Figure $2 \mathrm{~A}$ ). We also found that T4 DNA polymerase could increase the yield of the labeled products (compare lane 1 with lane 2 and lane 5 with lane 6 of Figure 2A). A possible reason is that T4 DNA polymerase repaired some damaged DNA templates during the nicking reaction. Additionally, 2 times of phenol extraction removed most of the digested labeled oligomers FL905 and FL924 (Figure 2A: compare lanes 1 and 2 with lanes 3 and 4; also compare lanes 5 and 6 with lanes 7 and 8). After isopropanol precipitation and dialysis steps, the fluorescently labeled plasmids pAB1_FL905 and pAB1_FL924 are free of the labeled oligomers and nicked or gapped $\overline{\mathrm{pAB}} 1$. To generate sc pAB1_FL905 or pAB1_FL924, $25 \mu \mathrm{M}$ of EB was added directly into the ligation reactions. We found that EB did not significantly affect ligation reactions (Figure S1). T5 exonuclease was able to remove nicked and gapped pAB1, and also oligomers FL905 and FL924 (Figure 2A). With this new method, we were capable of synthesizing milligrams of rx or sc pAB1_FL905 and pAB1_FL924 in 3-4 days with high yields.

In order to establish the relationship between the fluorescence intensity and the supercoiling density $(\sigma)$ of these fluorescently labeled plasmids, we relaxed sc pAB1_FL924 in the presence of increasing concentrations of EB using variola DNA topoisomerase I. After removing EB by phenol extraction and extensive dialysis, the fluorescence intensity of these DNA samples was measured and $\sigma$ was determined. ${ }^{39}$ Figure $2 \mathrm{~B}-\mathrm{E}$ shows our results. As expected, the fluorescence intensity was dependent on $\sigma$. When $\sigma$ of pAB1_FL924 $\leq-0.04$ with a $\Delta \mathrm{Lk} \leq-11$, the fluorescence intensity reached the minimum. This is consistent with previous results showing that the AT cruciform/hairpin was fully formed at $\sigma \leq-0.04 .^{40}$ As a result, the fluorescence was significantly quenched (Figure 2B). At $\sigma \geq-0.02$ with $\Delta \mathrm{Lk} \geq$ -5 , the hairpin structure disappeared and the fluorescence intensity increased sharply (Figure 2C). The supercoilingdependent fluorescence transition supports that these fluorescently labeled plasmids can be used to study kinetics of different DNA topoisomerases.

Steady-State Kinetics of Type I DNA Topoisomerases. With rx or sc pAB1_FL905 and pAB1_FL924, we carried out steady-state kinetic studies for 6 different DNA topo- 


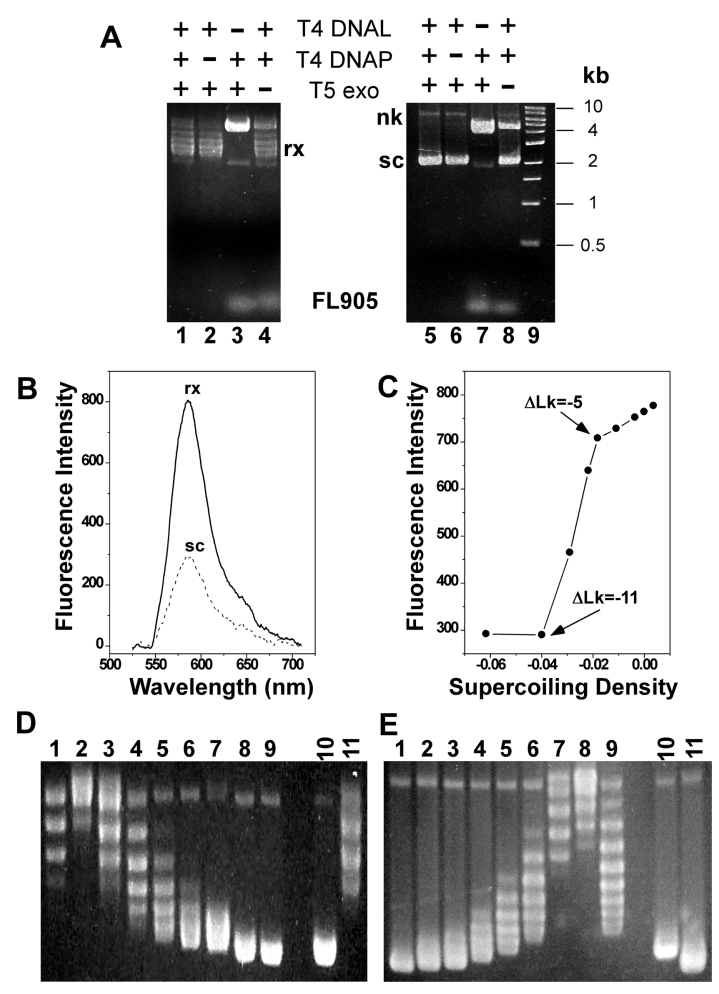

Figure 2. (A) Effects of different enzymes on the production of $r x$ and sc pAB1_FL905. rx (lanes 1-4) and sc (lanes 5-8) pAB1_FL905 were generated according to Figure 1 and also as described in "Materials and Methods." The DNA molecules were isolated and subjected to $1 \%$ agarose gel electrophoresis in $1 \times$ TAE buffer. Symbols and abbreviations: T4 DNAL, T4 DNA ligase; T4 DNAP, T4 DNA polymerase; T5 exo, T5 exonuclease; nk, nicked plasmid; sc, supercoiled plasmid; rx, relaxed plasmids; FL905, oligomer FL905. Lane 9 is the NEB $1 \mathrm{~kb}$ DNA ladder. (B) Fluorescence spectra of sc $(\sigma=-0.06$; dotted line $)$ and $\mathrm{rx}(\sigma=0$; solid line $)$ of pAB1 FL924 with $\lambda_{\text {ex }}=532 \mathrm{~nm}$. (C) Fluorescence intensity of pAB1_FL924 is dependent of supercoiling density $(\sigma)$. DNA topoisomeras with a mean $\Delta$ Lk were generated as described under Materials and Methods and used here. The fluorescence intensity of the same concentration of pAB1_FL924 samples was measured using a microplate reader with $\lambda_{\mathrm{ex}}=550 \mathrm{~nm}$ and $\lambda_{\mathrm{em}}=580 \mathrm{~nm}$. (D,E) Analysis of DNA topoisomers using $1 \%$ agarose gel electrophoreses in the absence (D) and presence of $2.5 \mu \mathrm{g} / \mathrm{mL}$ chloroquine (E) to determine the supercoiling density of different pAB1 FL924 samples. Lanes 1 to 9 are DNA samples relaxed by variola $\overline{D N A}$ topoisomerase $\mathrm{I}$ in the presence of $0,0.5,1$, $1.5,2,2.5,3.75,5$, and $7.5 \mu \mathrm{M}$ of $\mathrm{EB}$, respectively. Lanes 10 and 11 are supercoiled and relaxed pAB1, respectively.

isomerases. The first DNA topoisomerase we examined is $E$. coli DNA topoisomerase I, a $96 \mathrm{kDa}$ monomeric type IA topoisomerase. ${ }^{1}$ We kept E. coli DNA topoisomerase I concentration at $17 \mathrm{nM}$ and varied pAB1_FL905's concentration from 0.36 to $6.39 \mathrm{nM}$ (Figure 3). This condition is consistent with previously published conditions for testing $E$. coli topoisomerase I's activity using agarose gel electrophoresis. $^{34,41}$ Note that plasmid pAB1 is much larger than $E$. coli DNA topoisomerase I (1800 kDa vs $96 \mathrm{kDa})$ and sc pAB1_FL905 has $20(-)$ supercoils. Considering the fact that multiple E. coli DNA topoisomerase I can bind and remove (-) supercoils from each pAB1_FL905, our testing conditions should meet the requirements for steady-state kinetics. Nevertheless, addition of E. coli DNA topoisomerase I into a solution containing sc pAB1_FL905 caused a rapid increase of fluorescence intensity of the solution at $521 \mathrm{~nm}$
A

$\mathrm{sc}$ DNA + EcTop1 $\longrightarrow$ EcTop1-DNA $\longrightarrow \mathrm{rx}$ DNA + EcTop1
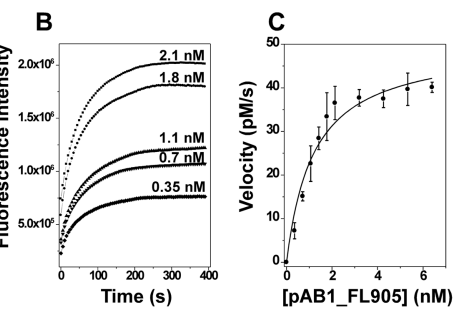

D

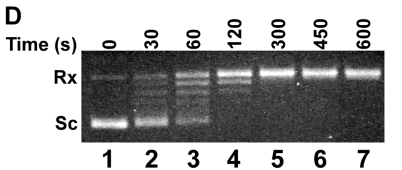

Figure 3. Steady-state kinetics of E. coli DNA topoisomerase I. (A) Proposed reaction scheme for the relaxation reaction catalyzed by $E$. coli DNA topoisomerase I. (B) Time courses of E. coli DNA topoisomerase I-catalyzed DNA relaxation reactions monitored by fluorescence intensity change. For the relaxation reaction, $60 \mu \mathrm{L}$ of $1 \times$ CutSmart buffer (50 mM KAc, $20 \mathrm{mM}$ Tris-Ac, $10 \mathrm{mM} \mathrm{Mg}(\mathrm{AC})_{2}$, $100 \mu \mathrm{g} / \mathrm{mL}$ BSA, $\mathrm{pH} 7.9)$ containing different concentrations of sc pAB1 FL905 was prepared and equilibrated to $37^{\circ} \mathrm{C}$, and $17 \mathrm{nM}$ of E. coli DNA topoisomerase I was used to relax the sc pAB1_FL905. The fluorescence intensity at $\lambda_{\mathrm{em}}=521 \mathrm{~nm}$ was monitored with $\lambda_{\mathrm{ex}}=$ $494 \mathrm{~nm}$ using a Horiba FluoroMax-3 spectrofluorimeter. (C) Initial velocities of relaxation reaction were calculated from (B), plotted against the substrate (pAB1_FL905) concentration, and fitted into the classical Michaelis-Menten equation to determine $K_{\mathrm{M}}, V_{\max }$, and $k_{\text {cat. }}$ (D) Time courses of $E$. coli DNA topoisomerase I-catalyzed DNA relaxation reactions monitored by $1 \%$ agarose gel electrophoresis; 465 $\mu \mathrm{L}$ of $1 \times$ CutSmart buffer (50 mM KAc, $20 \mathrm{mM}$ Tris-Ac, $10 \mathrm{mM}$ $\left.\mathrm{Mg}(\mathrm{AC})_{2}, 100 \mu \mathrm{g} / \mathrm{mL} \mathrm{BSA}, \mathrm{pH} 7.9\right)$ containing $2.13 \mathrm{nM}$ of sc pAB1 FL905 was prepared and equilibrated to $37{ }^{\circ} \mathrm{C}$, and $17 \mathrm{nM}$ of E. coli DNA topoisomerase I was used to relax the sc pAB1_FL905. The reactions were stopped by adding $20 \mathrm{mM}$ EDTA and $0 . \overline{1} \%$ SDS into the reaction mixtures. Lanes 1-7 represent DNA samples from 0 , $30,60,120,300,450$, and $600 \mathrm{~s}$ of the relaxation assay, respectively. rx and sc represent relaxed and supercoiled DNA molecules, respectively.

that reached plateau within 200-300 s (Figure 3B). Initial velocities were calculated from these time courses and successfully fitted to the Michaelis-Menten equation to yield a $K_{\mathrm{M}}$ of $1.2 \pm 0.3 \mathrm{nM}, V_{\max }$ of $50 \pm 4 \mathrm{pM} / \mathrm{s}$, and $k_{\text {cat }}$ of $3.0 \times$ $10^{-3} \mathrm{~s}^{-1}$. These values are lower than those that we obtained from agarose gel electrophoresis published previously. ${ }^{34}$ Possible reasons for this disparity include the following: (1) gel electrophoresis is not as quantitative for analyzing the kinetics of DNA topoisomerases. For example, the disappearance of the "most sc species" used in the agarose-gel based assays may not represent the real initial velocity of $E$. coli DNA topoisomerase I because the $1 \%$ agarose gels in the absence of chloroquine cannot differentiate the initial, less sc DNA products from the "most sc species"; (2) a different plasmid DNA template, that is, pXX6 (4483 bp) was used in our previous studies and is significantly larger than pAB1_FL905 used here; and (3) we used more E. coli DNA topoisomerase I in the current studies than in the previous studies ${ }^{34}$ ( 17 vs 8 $\mathrm{nM})$. The low turnover number $\left(k_{\text {cat }}, 3.0 \times 10^{-3} \mathrm{~s}^{-1}\right)$ suggests that E. coli DNA topoisomerase I is a "slow" enzyme. It should be noted however that the $k_{\text {cat }}$ values determined here represent the whole plasmid molecule involving multiple catalytic cycles along with the dissociation rate constant as the 
enzyme is released from relaxed DNA products. We also carried out a time course of the relaxation reaction of $E$. coli DNA topoisomerase I using agarose gel electrophoresis (Figure 3D). At $300 \mathrm{~s}$, all pAB1_FL905 is fully relaxed, which is consistent with our fluorescence results.

Previous studies showed that high salt concentrations inhibited the relaxation activities of E. coli DNA topoisomerase I and also changed the final topological status of the relaxed topoisomers. ${ }^{42}$ Here, we performed kinetic studies of E. coli topoisomerase I using plasmid pAB1_FL924 in two different solution conditions, $1 \times$ CutSmart buffer and $1 \times$ CutSmart buffer plus $100 \mathrm{mM} \mathrm{NaCl}$. Figure S2 shows the results. Indeed, high salt concentration decreased the fluorescence intensity of the final DNA topoisomers, presumably because of the topological status difference of the final relaxed topoisomers (Figure S2A), and also inhibited the relaxation activities of $E$. coli DNA topoisomerase I (Figure S2B). After fitting our kinetic data to the Michaelis-Menten equation, we obtained the following kinetic parameters: $K_{\mathrm{M}}$ of $1.2 \pm 0.2 \mathrm{nM}, V_{\max }$ of $51 \pm 4 \mathrm{pM} / \mathrm{s}$, and $k_{\text {cat }}$ of $3.0 \times 10^{-3} \mathrm{~s}^{-1}$ for $1 \times$ CutSmart buffer and $K_{\mathrm{M}}$ of $1.5 \pm 0.2 \mathrm{nM}, V_{\max }$ of $40 \pm 3 \mathrm{pM} / \mathrm{s}$, and $k_{\text {cat }}$ of $2.3 \times$ $10^{-3} \mathrm{~s}^{-1}$ for $1 \times$ CutSmart buffer plus $100 \mathrm{mM} \mathrm{NaCl}$. The $K_{\mathrm{M}}$ value does not change significantly, while $V_{\max }$ decreases in the high salt buffer condition, which is similar to the effect of a noncompetitive inhibitor of the enzyme.

M. smegmatis DNA topoisomerase I, a $110 \mathrm{kDa}$ monomeric type IA topoisomerase, ${ }^{43}$ was also examined. It is the only type IA DNA topoisomerase of M. smegmatis, essential for this bacterium, ${ }^{44,45}$ and a validated target for antibiotic discovery. ${ }^{13,44,46}$ In DNA relaxation time courses, we kept $M$. smegmatis DNA enzyme fixed at $13.3 \mathrm{nM}$ and varied DNA concentrations from 0.37 to $4.41 \mathrm{nM}$ (Figure S3). Similar to E. coli DNA topoisomerase I, M. smegmatis DNA topoisomerase I was able to fully relax sc pAB1_FL905 (Figure S3A,D). Initial velocities were calculated from these time courses and successfully fitted to the Michaelis-Menten equation to yield a $K_{\mathrm{M}}$ of $4.3 \pm 3.0 \mathrm{nM}, V_{\max }$ of $130 \pm 5 \mathrm{pM} / \mathrm{s}$, and $k_{\text {cat }}$ of $9.8 \times$ $10^{-3} \mathrm{~s}^{-1}$. The $K_{\mathrm{M}}$ value is slighter higher than that of $E$. coli DNA topoisomerase I and may be due to the divergent Cterminal domains. ${ }^{47}$ Again, the turnover number $\left(k_{\text {cat }}, 9.8 \times\right.$ $\left.10^{-3} \mathrm{~s}^{-1}\right)$ is rather low indicating that M. smegmatis DNA topoisomerase I is also a comparatively "slow" enzyme.

Additionally, two type IB DNA topoisomerases, variola and human DNA topoisomerase I, were examined. Both enzymes can relax (+) and (-) DNA supercoiling. ${ }^{1,48}$ Variola DNA topoisomerase I is the smallest topoisomerase (314 aa residues, $\sim 36.6 \mathrm{kDa}$; variola DNA topoisomerase I is similar to another poxvirus vaccinia topoisomerase I except for 3 amino acids ${ }^{48,49}$ ). Figure 4 shows the steady-state kinetics of variola DNA topoisomerase I. The $K_{\mathrm{M}}, V_{\max }$ and $k_{\text {cat }}$ were determined to be $2.4 \pm 1.0 \mathrm{nM}, 120 \pm 23 \mathrm{pM} / \mathrm{s}$, and $6.0 \times 10^{-3} \mathrm{~s}^{-1}$, respectively. Human topoisomerase $\mathrm{I}$ is a $90.7 \mathrm{kDa}$ monomer (765 aa residues $)^{1}$ and an important anticancer drug target. ${ }^{50}$ Notably, topoisomerase I inhibitors irinotecan and topotecan, derivatives of camptothecin, are highly effective FDA approved anticancer drugs. ${ }^{51}$ Interestingly, more recent studies showed that human topoisomerase I relaxation activity is related to autism spectrum disorder ${ }^{52}$ and inflammation. ${ }^{53}$ Figure 5 shows the results of steady-state kinetic studies of human DNA topoisomerase I. Apparently, it follows the classic MichaelisMenten kinetics. The $K_{\mathrm{M}}, V_{\max }$ and $k_{\text {cat }}$ were determined to be $2.7 \pm 1.00 \mathrm{nM}, 31 \pm 5 \mathrm{pM} / \mathrm{s}$, and $1.2 \times 10^{-3} \mathrm{~s}^{-1}$, respectively.
A

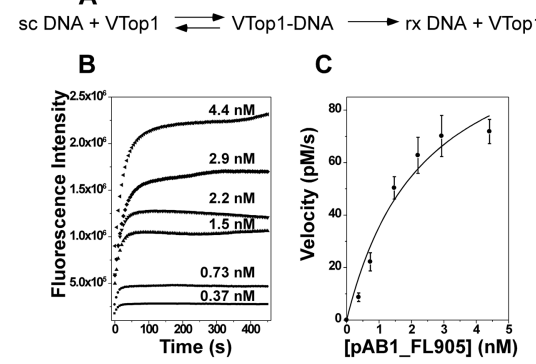

D

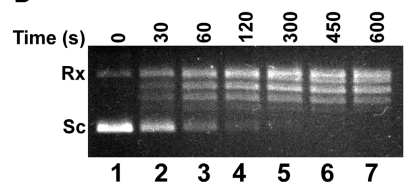

Figure 4. Steady-state kinetics of variola DNA topoisomerase I. (A) Proposed reaction scheme for the relaxation reaction catalyzed by variola DNA topoisomerase I. (B) Time courses of variola DNA topoisomerase I-catalyzed DNA relaxation reactions monitored by fluorescence intensity change. For the relaxation reaction, $60 \mu \mathrm{L}$ of $1 \times$ CutSmart buffer ( $50 \mathrm{mM}$ KAc, $20 \mathrm{mM}$ Tris-Ac, $10 \mathrm{mM} \mathrm{Mg}(\mathrm{AC})_{2}$, $100 \mu \mathrm{g} / \mathrm{mL}$ BSA, $\mathrm{pH} 7.9)$ containing different concentrations of sc pAB1_FL905 was prepared and equilibrated to $37{ }^{\circ} \mathrm{C}$, and $20 \mathrm{nM}$ of variola DNA topoisomerase I was used to relax the sc pAB1_FL905. The fluorescence intensity at $\lambda_{\mathrm{em}}=521 \mathrm{~nm}$ was monitored with $\lambda_{\mathrm{ex}}=$ 494 nm using a Horiba FluoroMax-3 spectrofluorimeter. (C) Initial velocities of relaxation reaction were calculated from (B), plotted against the substrate (pAB1_FL905) concentration, and fitted into the classical Michaelis-Menten equation to determine $K_{\mathrm{M}}, V_{\max }$ and $k_{\text {cat }}$ (D) Time courses of variola DNA topoisomerase I-catalyzed DNA relaxation reactions monitored by $1 \%$ agarose gel electrophoresis; $450 \mu \mathrm{L}$ of $1 \times$ CutSmart buffer ( $50 \mathrm{mM}$ KAc, $20 \mathrm{mM}$ TrisAc, $10 \mathrm{mM} \mathrm{Mg}(\mathrm{AC})_{2}, 100 \mu \mathrm{g} / \mathrm{mL}$ BSA, $\mathrm{pH} 7.9$ ) containing $2.2 \mathrm{nM}$ of sc pAB1_FL905 was prepared and equilibrated to $37^{\circ} \mathrm{C}$, and $20 \mathrm{nM}$ of variola DNA topoisomerase I was used to relax the sc pAB1_FL905. The reactions were stopped by adding $20 \mathrm{mM}$ EDTA and $0.1 \%$ SDS into the reaction mixtures. Lanes $1-7$ represent DNA samples from $0,30,60,120,300,450$, and $600 \mathrm{~s}$ of the relaxation assay, respectively. $\mathrm{rx}$ and $\mathrm{sc}$ represent relaxed and supercoiled DNA molecules, respectively.

Steady-State Kinetics of Type IIA DNA Topoisomerases. Next, we studied the steady-state kinetics of the type IIA DNA topoisomerases, E. coli DNA gyrase, and human DNA topoisomerase II $\alpha$. Both enzymes require ATP for catalytic activity. ${ }^{1}$ E. coli DNA gyrase is a tetrameric protein and contains two different kinds of subunits, gyrA and gyrB that form an active $\mathrm{A}_{2} \mathrm{~B}_{2}$ complex. ${ }^{1}$ DNA gyrase is the only known DNA topoisomerase that actively introduces (-) supercoils in DNA substrates under normal reaction conditions and therefore requires hydrolysis of ATP. ${ }^{1-3}$ DNA gyrase only exists in bacteria, is an essential enzyme, ${ }^{54-56}$ and could be used to identify inhibitors without significantly affecting host human enzymes. ${ }^{10,57}$ Figures 6 and S4 show our kinetic results. Addition of DNA gyrase to solutions containing $r x$ pAB1_FL905 resulted in a significant decrease of the fluorescence intensity of the solution at $521 \mathrm{~nm}$ that reached the plateau within $300-400 \mathrm{~s}$ (Figure $6 \mathrm{~B}$ ) and a complete $(-$ ) supercoiling of the rx pAB1 FL905 (Figure 6C). Because E. coli gyrase has two substrates, rx DNA pAB1_FL905 and ATP, we determined the pseudo first-order kinetics for both substrates by fitting the initial velocity results to the Michaelis-Menten equation (Figure 6D,E). For rx DNA pAB1_FL905, we kept the ATP concentration at $1.75 \mathrm{mM}$ and 


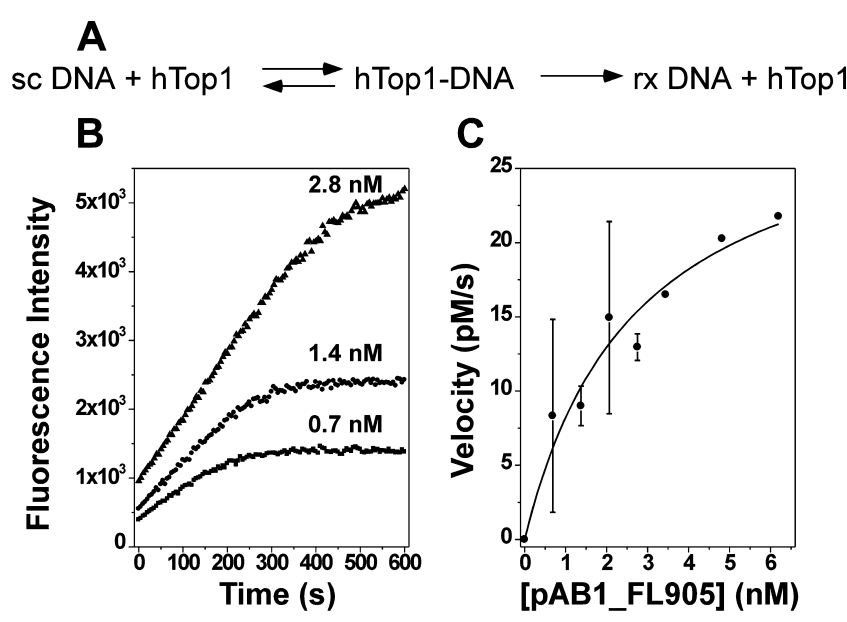

Figure 5. Steady-state kinetics of human DNA topoisomerase I. (A) Proposed reaction scheme for the relaxation reaction catalyzed by human DNA topoisomerase I. (B) Time courses of human DNA topoisomerase I-catalyzed DNA relaxation reactions monitored by fluorescence intensity change. For the relaxation reaction, $60 \mu \mathrm{L}$ of $1 \times$ human Top1 buffer (10 mM Tris-Cl, pH 7.9, $150 \mathrm{mM} \mathrm{NaCl}, 0.1 \%$ BSA, $0.1 \mathrm{mM}$ spermidine, $5 \%$ glycerol) containing different concentrations of sc pAB1 FL905 was prepared and equilibrated to $37^{\circ} \mathrm{C}$, and $25 \mathrm{nM}$ of human DNA topoisomerase I was used to relax the sc pAB1_FL905. The fluorescence intensity at $\lambda_{\mathrm{em}}=521 \mathrm{~nm}$ was monitored using a Biotek Synergy H1 Hybrid Plate Reader with an excitation wavelength of $482 \mathrm{~nm}$. (C) Initial velocities of relaxation reaction were calculated from (B), plotted against the substrate (pAB1_FL905) concentration, and fitted into the classical MichaelisMenten equation to determine $K_{\mathrm{M}}, V_{\max }$, and $k_{\text {cat }}$.

varied DNA concentration from 0.75 to $7.2 \mathrm{nM}$ to yield a $K_{\mathrm{M}}$, $V_{\max }$ and $k_{\text {cat }}$ of $2.7 \pm 0.2 \mathrm{nM}, 50 \pm 2 \mathrm{pM} / \mathrm{s}$, and $1.1 \times 10^{-3}$ $\mathrm{s}^{-1}$, respectively. For ATP, we kept the concentration of $\mathrm{rx}$ pAB1 FL905 at $7.2 \mathrm{nM}$ and varied the ATP concentration from $0.1 \mathrm{mM}$ to $2 \mathrm{mM}$ to generate a $K_{\mathrm{M}}$ and $V_{\max }$ of $0.33 \pm$ $0.14 \mathrm{mM}$ and $50 \pm 7 \mathrm{pM} / \mathrm{s}$, respectively. The $K_{\mathrm{M}}$ values of DNA gyrase are consistent with previously published results using ATPase assays ${ }^{58,59}$ and single-molecule techniques. ${ }^{60}$

Previously, it was demonstrated that novobiocin is a competitive inhibitor of DNA gyrase to prevent ATP binding to gyrase subunit B. ${ }^{61}$ In this study, we also performed kinetic studies of E. coli DNA gyrase in the absence and presence of 60 $\mathrm{nM}$ of novobiocin. Figure 7 shows our results. As expected, novobiocin significantly inhibited the supercoiling reaction of E. coli DNA gyrase (Figure 7A). Fitting of these kinetics to the Michaelis-Menten equation produced the following kinetic parameters: $K_{\mathrm{M}}$ of $0.4 \pm 0.1 \mathrm{mM}$ and $V_{\max }$ of $50 \pm 3 \mathrm{pM} / \mathrm{s}$ in the absence of novobiocin and $K_{\mathrm{M}}$ of $2.4 \pm 0.1 \mathrm{mM}$ and $V_{\max }$ of $50 \pm 2 \mathrm{pM} / \mathrm{s}$ in the presence of $60 \mathrm{nM}$ novobiocin. $V_{\max }$ is identical while $K_{\mathrm{M}}$ is significantly higher in the presence of novobiocin. This result demonstrates that novobiocin is a competitive inhibitor of ATP for E. coli DNA gyrase. In the Lineweaver-Burk or double-reciprocal plot, the intercept on the $y$-axis of the plot of $1 / V_{0}$ versus $1 /[\mathrm{ATP}]$ is the same in the presence or absence of novobiocin showing that novobiocin competes with ATP for its binding sites on E. coli DNA gyrase. The $K_{\mathrm{i}}$ value was calculated to be $11.6 \mathrm{nM}$ which is consistent with the previous determination. ${ }^{61}$

Human DNA topoisomerase II $\alpha$ is a homodimer with 1531 residues and $174385 \mathrm{Da}$ per monomer. ${ }^{1,62}$ It can relax both $(-)$ and $(+)$ supercoiled DNA in the presence of $\mathrm{ATP}^{1}$ and plays an essential role during mitosis and meiosis as a

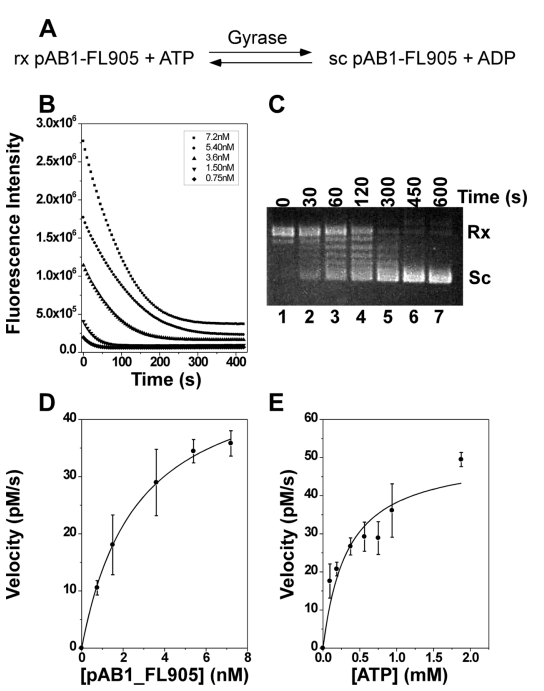

Figure 6. Steady-state kinetics of E. coli DNA gyrase. (A) Proposed reaction scheme for the supercoiling reaction catalyzed by E. coli DNA gyrase. The reaction includes two substrates: ATP and DNA (pAB1_FL905). (B) Time courses of E. coli DNA gyrase-catalyzed DNA supercoiling reactions monitored by fluorescence intensity change. For the supercoiling reaction, $60 \mu \mathrm{L}$ of $1 \times$ DNA gyrase buffer (35 mM Tris- $\mathrm{HCl}, 24 \mathrm{mM} \mathrm{KCl}, 4 \mathrm{mM} \mathrm{MgCl}, 2 \mathrm{mM}$ DTT, $1.75 \mathrm{mM}$ ATP, $5 \mathrm{mM}$ spermidine, $0.1 \mathrm{mg} / \mathrm{mL}$ BSA, $6.5 \%$ glycerol, $\mathrm{pH} 7.5$ ) containing different concentrations of $\mathrm{rx}$ pAB1 FL905 was prepared and equilibrated to $37{ }^{\circ} \mathrm{C}$, and $44.6 \mathrm{nM}$ of E. coli DNA gyrase was used to supercoil the $\mathrm{rxpAB} 1$ FL905. The fluorescence intensity at $\lambda_{\mathrm{em}}=521 \mathrm{~nm}$ was monitore $\overline{\mathrm{d}}$ with $\lambda_{\mathrm{ex}}=494 \mathrm{~nm}$ using a Horiba FluoroMax-3 spectrofluorimeter. (C) Time courses of E. coli DNA gyrase-catalyzed DNA supercoiling reactions monitored by $1 \%$ agarose gel electrophoresis. $384 \mu \mathrm{L}$ of $1 \times$ DNA gyrase buffer containing 7.2 $\mathrm{nM}$ of $\mathrm{rx}$ pAB1_FL905 was prepared and equilibrated to $37^{\circ} \mathrm{C}$, and $44.6 \mathrm{nM}$ of $E$. coli DNA gyrase was used to supercoil the rx pAB1 FL905. The reactions were stopped by adding $20 \mathrm{mM}$ EDTA and $0.1 \%$ SDS into the reaction mixtures. Lanes $1-7$ represent DNA samples from $0,30,60,120,300,450$, and $600 \mathrm{~s}$ of the supercoiling assay, respectively. $\mathrm{rx}$ and sc represent relaxed and supercoiled DNA molecules, respectively. (D) Initial velocities of supercoiling reaction were calculated from (B), plotted against the substrate (sc pAB1_FL905) concentration, and fitted into the classical Michaelis-Menten equation to determine $K_{\mathrm{M}}, V_{\max }$ and $k_{\text {cat }}$ for the DNA substrate (rx pAB1_FL905). (E) Initial velocities of supercoiling reaction were plotted against ATP concentration and fitted into the classical Michaelis-Menten equation to determine $K_{M}$ and $V_{\max }$ for ATP.

decatenase. ${ }^{63}$ This enzyme is also a target of several important anticancer drugs, including doxorubicin and etopside. ${ }^{10,64}$ Similar to DNA gyrase, human DNA topoisomerase II $\alpha$ has two substrates, sc plasmid DNA and ATP. Therefore, we determined the pseudo first order steady-state kinetic parameters for both substrates (Figure S5). For sc DNA pAB1_FL924, we kept the ATP concentration at $2 \mathrm{mM}$ and varied DNA concentration from 1.3 to $8 \mathrm{nM}$ to yield $K_{\mathrm{M}}, V_{\max }$ and $k_{\text {cat }}$ of $5.7 \pm 1.5 \mathrm{nM}, 187 \pm 25 \mathrm{pM} / \mathrm{s}$, and $6.7 \times 10^{-3} \mathrm{~s}^{-1}$, respectively. For ATP, we kept the concentration of sc pAB1_FL924 at $4 \mathrm{nM}$ and varied the ATP concentration from $0.025 \overline{\mathrm{mM}}$ to $2 \mathrm{mM}$ to generate a $K_{\mathrm{M}}$ and $V_{\max }$ of $0.22 \pm 0.06$ $\mathrm{mM}$ and $99 \pm 8 \mathrm{pM} / \mathrm{s}$, respectively. The $K_{\mathrm{M}}$ value of human DNA topoisomerase II $\alpha$ is consistent with previously published results using ATPase assays ${ }^{65-68}$ and singlemolecule techniques ${ }^{22}$ for human and other eukaryotic DNA topoisomerase II $\alpha$. 

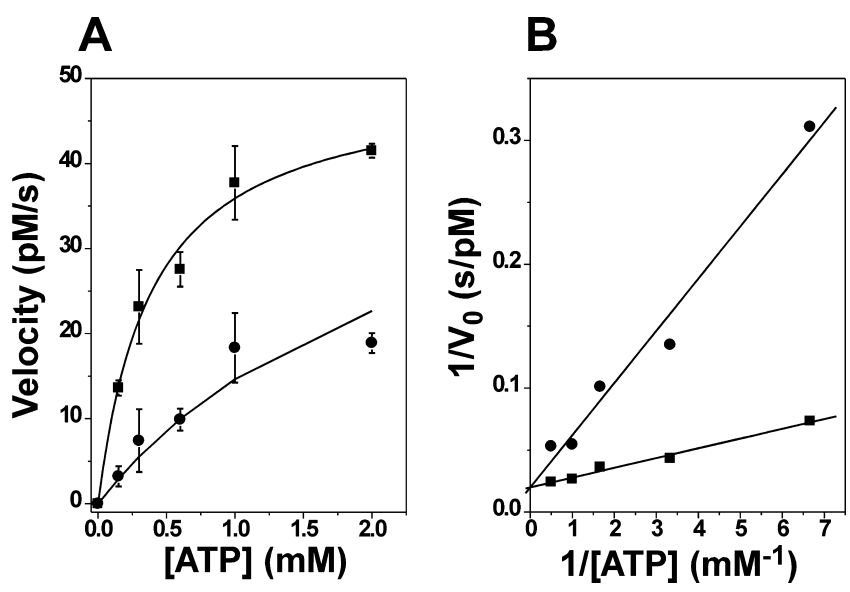

Figure 7. Novobiocin is a competitive inhibitor of E. coli DNA gyrase to prevent ATP binding. (A) Inhibition of E. coli DNA gyrase catalyzed supercoiling reaction as a function of ATP. DNA supercoiling reactions were performed as described in "Materials and Methods" and also in the legend of Figure 6. The kinetic results were fitted to the classical Michaelis-Menten equation to yield $K_{\mathrm{M}}$, $K_{\mathrm{i}}$ and $V_{\text {max. }}$ (B) Lineweaver-Burk plot or double-reciprocal plot of E. coli DNA gyrase in the absence or presence of novobiocin. Closed circles and squares represent supercoiling reactions in the absence and presence of $60 \mathrm{nM}$ novobiocin, respectively.

\section{SUMMARY}

Table 1 summarizes the steady-state kinetic parameters for 6 DNA topoisomerases that we examined in this study. The Michaelis constants of these topoisomerases are all in the nanomolar range. Because $K_{\mathrm{M}}$ can be used to estimate the strength of the enzyme substrate (ES) complex (Figure 8A), low $K_{\mathrm{M}}$ values indicate strong binding of topoisomerases to DNA, which is consistent with previously published results. ${ }^{34,69}$ Intriguingly, the $k_{\text {cat }}$ values of these 6 DNA topoisomerases are all low (Table 1). To explain this, we are considering a kinetic pathway for topoisomerases (Figure 8B). The enzyme and substrate form an ES complex and become an enzyme-product complex through an activation ES* state. After relaxation or supercoiling steps, the topoisomerases may
A

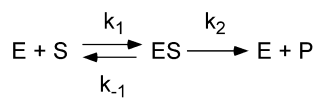

B $\mathrm{E}+\mathrm{S} \underset{\mathrm{k}_{-1}}{\stackrel{\mathrm{k}_{1}}{\longrightarrow}} \mathrm{ES} \longrightarrow \mathrm{ES}^{*} \stackrel{\mathrm{k}_{2}}{\longrightarrow} \mathrm{EP} \stackrel{\mathrm{k}_{\text {off }}}{\longrightarrow} \mathrm{E}+\mathrm{P}$

Figure 8. (A) Simplified reaction pathway for the classical MichaelisMenten enzyme kinetics. (B) Proposed kinetic pathway for DNA topoisomerases. DNA topoisomerases may need to dissociate from the DNA product before the next round of catalysis. $k_{\text {off }}$ represents the off rate constant for DNA topoisomerases dissociating from the product.

need to dissociate from the DNA product for the next round of catalysis. If topoisomerases still tightly bind to their product, $k_{\text {off }}$ should be low, which yields a low $k_{\text {cat }}$. Indeed, the $k_{\text {off }}$ value of $E$. coli DNA topoisomerase I was determined previously and shown to be quite low $^{69}\left(0.017-0.043 \mathrm{~s}^{-1}\right)$. In other words, the low values of $k_{\text {cat }}$ of $E$. coli DNA topoisomerase I stem from its tight binding to DNA. Recently, it was reported that Streptomyces coelicolor DNA topoisomerase I is a highly processive enzymes and can relax $\sim 150(-)$ supercoils in a single burst in the single-molecule assay. ${ }^{70}$ Steady-state kinetic parameters were also determined using a gel-based assay and pUC $18^{34}$ to yield a $K_{\mathrm{M}}$ of $5.1 \mathrm{nM}$ and a $V_{\max }$ of $108 \mathrm{pM} / \mathrm{s}(6.5$ $\mathrm{nM} / \mathrm{min}){ }^{70}$ Because $5 \mathrm{nM}$ of DNA topoisomerase I was used, this produces a $k_{\text {cat }}$ of $2.2 \times 10^{-2} \mathrm{~s}^{-1}$, comparable to $k_{\text {cat }}$ values determined in this article (Table 1). Although the SDFQ method provides quantitative measurements for kinetic studies of DNA topoisomerases, we noticed some limitations for this method. This assay cannot be used to measure relaxation of (+) sc DNA. Additionally, this method only works in a relative narrow range of $\sigma$, that is, $-0.02 \geq \sigma \geq-0.04$ and cannot be used to study the transition of hypernegatively sc DNA to (-) sc DNA with $\sigma \leq-0.04$.

In conclusion, we developed a rapid and efficient method to generate rx and sc fluorescently labeled plasmid DNA molecules for DNA topoisomerases. Utilizing the fluorescently labeled rx and sc pAB1_FL905 and pAB1_FL924, we found that all 6 DNA topoisomerases including type IA, IB, and IIA topoisomerases follow the classical Michaelis-Menten kinetics.

Table 1. Steady-State Kinetic Parameters for DNA Topoisomerases

\begin{tabular}{|c|c|c|c|c|}
\hline enzyme $^{a}$ & subfamily type & $K_{\mathrm{M}}(\mathrm{nM})$ & $V_{\max }(\mathrm{pM} / \mathrm{s})$ & $k_{\text {cat }}\left(\mathrm{s}^{-1}\right)$ \\
\hline \multirow[t]{3}{*}{ EcTopI } & IA & $1.2 \pm 0.3^{b}$ & $50 \pm 4^{b}$ & $3.0 \times 10^{-3 b}$ \\
\hline & & $1.5 \pm 0.2^{c}$ & $40 \pm 3^{c}$ & $2.3 \times 10^{-3 c}$ \\
\hline & & $7.5 \pm 2.2(\operatorname{ref} 34)^{d}$ & $8.0 \pm 1.0(\text { ref } 34)^{d}$ & $1.2 \pm 0.5(\text { ref } 34)^{d}$ \\
\hline MsTopI & IA & $4.3 \pm 3.0$ & $130 \pm 5$ & $9.8 \times 10^{-3}$ \\
\hline vTopI & IB & $2.4 \pm 1.0$ & $120 \pm 23$ & $6.0 \times 10^{-3}$ \\
\hline hTopI & IB & $2.7 \pm 1.0$ & $31 \pm 5$ & $1.2 \times 10^{-3}$ \\
\hline EcGyrase & IIA & $2.7 \pm 0.2$ & $50 \pm 2$ & $1.1 \times 10^{-3}$ \\
\hline EcGyrase $^{e}$ (ATP, mM) & IIA & $\begin{array}{l}0.33 \pm 0.14 \\
0.3(\text { refs } 58 \text { and } 61)^{d} \\
0.16(\operatorname{ref} 60)^{d}\end{array}$ & $51 \pm 7$ & \\
\hline hTopII $\alpha$ & IIA & $5.7 \pm 1.5$ & $187 \pm 25$ & $6.7 \times 10^{-3}$ \\
\hline hTopII $\alpha^{e}$ (ATP, mM) & IIA & $\begin{array}{l}0.2 \pm 0.1 \\
0.56 \pm 0.17(\text { ref } 65)^{d} \\
0.5 \pm 0.3(\text { ref } 68)^{d}\end{array}$ & $99 \pm 8$ & \\
\hline
\end{tabular}

${ }^{a}$ EcTopI, E. coli DNA topoisomerase I; MsTopI, M. smegmatis DNA topoisomerase I; vTopI, variola DNA topoisomerase I; hTopI, human topoisomerase I; EcGyrase, E. coli DNA gyrase; hTopII $\alpha$, human DNA topoisomerase II $\alpha$. ${ }^{b}$ These kinetic parameters were determined in $1 \times$ CutSmart buffer. ${ }^{c}$ These kinetic parameters were determined in $1 \times$ CutSmart buffer plus $100 \mathrm{mM} \mathrm{NaCl}$. ${ }^{d}$ These values were determined in the cited references. ${ }^{e}$ The concentration unit for $K_{\mathrm{M}}$ of ATP is $\mathrm{mM}$. 
We determined the steady-state kinetic parameters, that is, $K_{\mathrm{M}}$, $V_{\text {max }}$ and $k_{\text {cat }}$, for these DNA topoisomerases. Using this kinetic study, we also confirmed that novobiocin is a competitive inhibitor of DNA gyrase to prevent ATP binding.

\section{ASSOCIATED CONTENT}

\section{S Supporting Information}

The Supporting Information is available free of charge on the ACS Publications website at DOI: 10.1021/acsomega.9b02676.

Effects of EB on the supercoiling status of pAB1_FL905; effects of $\mathrm{NaCl}$ on the kinetics of E. coli topoisomerase I; steady-state kinetics of $M$. smegmatis DNA topoisomerase I; time courses of E. coli DNA gyrase-catalyzed DNA supercoiling reactions monitored by fluorescence intensity change in the presence of 1 or $2 \mathrm{mM}$ of ATP; and steady-state kinetics of human DNA topoisomerase $\mathrm{II} \alpha$ (PDF)

\section{Accession Codes}

The following are accession codes from UniProt for the proteins used in this article: E. coli DNA topoisomerase I, P06612; E. coli DNA gyrase subunit A, P0AES4; E. coli DNA gyrase subunit B, P0AES6; $M$. smegmatis DNA topoisomerase I, A0R5D9; Variola DNA topoisomerase I, P32989; human DNA topoisomerase I, P11387; human DNA topoisomerase II $\alpha, \mathrm{P} 11388$.

\section{AUTHOR INFORMATION}

\section{Corresponding Author}

*E-mail: lengf@fiu.edu. Phone: 305-348-3277. Fax: 305-3483772.

ORCID $\odot$

John L. Nitiss: 0000-0002-1013-4972

Fenfei Leng: 0000-0002-9024-1216

\section{Author Contributions}

F.L. designed research; Y.W., S.R., and F.L. performed research; F.L., J.W.C., Z.-C.H., J.L.N., and Y.-C.T.-D. analyzed data; M.T.M. and J.L.N. provided critical reagents; F.L. wrote the paper.

\section{Notes}

The authors declare no competing financial interest.

\section{ACKNOWLEDGMENTS}

This work was supported by grants 1R15GM109254-01A1 and 1R21AI125973-01A1 from the National Institutes of Health (to F.L.). We thank Dr. H Peter Lu at Bowling Green State University, and Drs. Geoff Wilson and Gregory J. Lohman at New England Biolabs, Inc. for helpful discussion. Additional support was from NIH Grant R43GM113286 (to M.T.M.), a State of Colorado Advanced Industry Grant from the Office of Economic Development and International Trade (grant number CTGG1-2016-1825 to M.T.M.), and BZ2018017 from the Jiangsu Department of Science and Technology of China (to Z.C.H.).

\section{ABBREVIATIONS}

rx, relaxed; sc, supercoiled; nk, nicked; FRET, fluorescence resonance energy transfer; SDFQ supercoiling dependent fluorescence quenching

\section{REFERENCES}

(1) Champoux, J. J. DNA topoisomerases: structure, function, and mechanism. Annu. Rev. Biochem. 2001, 70, 369-413.

(2) Schoeffler, A. J.; Berger, J. M. DNA topoisomerases: harnessing and constraining energy to govern chromosome topology. Q. Rev. Biophys. 2008, 41, 41-101.

(3) Wang, J. C. DNA topoisomerases. Annu. Rev. Biochem. 1996, 65, 635-692.

(4) Bush, N. G.; Evans-Roberts, K.; Maxwell, A. DNA Topoisomerases. EcoSal Plus, 2015, 6. DOI: 10.1128/ecosalplus.esp-00102014

(5) Watson, J. D.; Crick, F. H. C. Genetical implications of the structure of deoxyribonucleic acid. Nature 1953, 171, 964-967.

(6) Cozzarelli, N. R.; Boles, T. C.; White, J. H. A Primer on the Topology and Geometry of DNA Supercoiling. In DNA Topology and Its Biological Effects; Cozzarelli, N. R., Wang, J. C., Eds.; Cold Spring Harbor Laboratory Press: Cold Spring Harbor, New York, 1990; Vol 11724, pp 139-184.

(7) Bates, A. D.; Maxwell, A. DNA Topology; Oxford University Press: Oxford, U.K., 2005.

(8) Wang, J. C. Untangling the Double Helix: DNA Entanglement and the Action of the DNA Topoisomerases; Cold Spring Harbor Laboratory Press: Cold Spring Harbor, New York, 2008.

(9) Pommier, Y.; Sun, Y.; Huang, S.-y. N.; Nitiss, J. L. Roles of eukaryotic topoisomerases in transcription, replication and genomic stability. Nat. Rev. Mol. Cell Biol. 2016, 17, 703-721.

(10) Pommier, Y. Drugging topoisomerases: lessons and challenges. ACS Chem. Biol. 2013, 8, 82-95.

(11) Cuya, S. M.; Bjornsti, M.-A.; van Waardenburg, R. C. A. M. DNA topoisomerase-targeting chemotherapeutics: what's new? Cancer Chemother. Pharmacol. 2017, 80, 1-14.

(12) Pommier, Y. DNA topoisomerase I inhibitors: chemistry, biology, and interfacial inhibition. Chem. Rev. 2009, 109, 2894-2902.

(13) Nagaraja, V.; Godbole, A. A.; Henderson, S. R.; Maxwell, A. DNA topoisomerase I and DNA gyrase as targets for TB therapy. Drug Discovery Today 2017, 22, 510-518.

(14) Tse-Dinh, Y.-C. Targeting bacterial topoisomerases: how to counter mechanisms of resistance. Future Med. Chem. 2016, 8, 10851100.

(15) Aldred, K. J.; Kerns, R. J.; Osheroff, N. Mechanism of quinolone action and resistance. Biochemistry 2014, 53, 1565-1574.

(16) Keller, W. Determination of the number of superhelical turns in simian virus 40 DNA by gel electrophoresis. Proc. Natl. Acad. Sci. U.S.A. 1975, 72, 4876-4880.

(17) Depew, D. E.; Wang, J. C. Conformational fluctuations of DNA helix. Proc. Natl. Acad. Sci. U.S.A. 1975, 72, 4275-4279.

(18) Charvin, G.; Strick, T. R.; Bensimon, D.; Croquette, V. Tracking topoisomerase activity at the single-molecule level. Annu. Rev. Biophys. Biomol. Struct. 2005, 34, 201-219.

(19) Bryant, Z.; Oberstrass, F. C.; Basu, A. Recent developments in single-molecule DNA mechanics. Curr. Opin. Struct. Biol. 2012, 22, 304-312.

(20) Neuman, K. C. Single-molecule measurements of DNA topology and topoisomerases. J. Biol. Chem. 2010, 285, 18967-18971.

(21) Terekhova, K.; Marko, J. F.; Mondragón, A. Studies of bacterial topoisomerases I and III at the single-molecule level. Biochem. Soc. Trans. 2013, 41, 571-575.

(22) Strick, T. R.; Croquette, V.; Bensimon, D. Single-molecule analysis of DNA uncoiling by a type II topoisomerase. Nature 2000, 404, 901-904.

(23) Gore, J.; Bryant, Z.; Stone, M. D.; Nöllmann, M.; Cozzarelli, N. R.; Bustamante, C. Mechanochemical analysis of DNA gyrase using rotor bead tracking. Nature 2006, 439, 100-104.

(24) Nöllmann, M.; Stone, M. D.; Bryant, Z.; Gore, J.; Crisona, N. J.; Hong, S.-C.; Mitelheiser, S.; Maxwell, A.; Bustamante, C.; Cozzarelli, N. R. Multiple modes of Escherichia coli DNA gyrase activity revealed by force and torque. Nat. Struct. Mol. Biol. 2007, 14, 264-271. 
(25) Neuman, K. C.; Charvin, G.; Bensimon, D.; Croquette, V. Mechanisms of chiral discrimination by topoisomerase IV. Proc. Natl. Acad. Sci. U.S.A. 2009, 106, 6986-6991.

(26) Seol, Y.; Zhang, H.; Pommier, Y.; Neuman, K. C. A kinetic clutch governs religation by type IB topoisomerases and determines camptothecin sensitivity. Proc. Natl. Acad. Sci. U.S.A. 2012, 109, 16125-16130.

(27) Terekhova, K.; Marko, J. F.; Mondragón, A. Single-molecule analysis uncovers the difference between the kinetics of DNA decatenation by bacterial topoisomerases I and III. Nucleic Acids Res. 2014, 42, 11657-11667.

(28) Koster, D. A.; Croquette, V.; Dekker, C.; Shuman, S.; Dekker, $\mathrm{N}$. H. Friction and torque govern the relaxation of DNA supercoils by eukaryotic topoisomerase IB. Nature 2005, 434, 671-674.

(29) Hartmann, S.; Gubaev, A.; Klostermeier, D. Binding and Hydrolysis of a Single ATP Is Sufficient for N-Gate Closure and DNA Supercoiling by Gyrase. J. Mol. Biol. 2017, 429, 3717-3729.

(30) Seol, Y.; Neuman, K. C. Single-Molecule Measurements of Topoisomerase Activity with Magnetic Tweezers. Single Molecule Enzymology, 2011; Vol 778, pp 229-241.

(31) Gu, M.; Berrido, A.; Gonzalez, W. G.; Miksovska, J.; Chambers, J. W.; Leng, F. Fluorescently labeled circular DNA molecules for DNA topology and topoisomerases. Sci. Rep. 2016, 6, 36006.

(32) Greaves, D. R.; Patient, R. K.; Lilley, D. M. J. Facile cruciform formation by an (A-T)34 sequence from a Xenopus globin gene. $J$. Mol. Biol. 1985, 185, 461-478.

(33) Panyutin, I.; Lyamichev, V.; Mirkin, S. A structural transition in $\mathrm{d}(\mathrm{AT}) \mathrm{n} . \mathrm{d}(\mathrm{AT}) \mathrm{n}$ inserts within superhelical DNA. J. Biomol. Struct. Dyn. 1985, 2, 1221-1234.

(34) Xu, X.; Leng, F. A rapid procedure to purify Escherichia coli DNA topoisomerase I. Protein Expression Purif. 2011, 77, 214-219.

(35) Hallett, P.; Grimshaw, A. J.; Wigley, D. B.; Maxwell, A. Cloning of the DNA gyrase genes under tac promoter control: overproduction of the gyrase A and B proteins. Gene 1990, 93, 139-142.

(36) Ahmad, M.; Xue, Y.; Lee, S. K.; Martindale, J. L.; Shen, W.; Li, W.; Zou, S.; Ciaramella, M.; Debat, H.; Nadal, M.; Leng, F.; Zhang, H.; Wang, Q.; Siaw, G. E.-L.; Niu, H.; Pommier, Y.; Gorospe, M.; Hsieh, T.-S.; Tse-Dinh, Y.-C.; Xu, D.; Wang, W. RNA topoisomerase is prevalent in all domains of life and associates with polyribosomes in animals. Nucleic Acids Res. 2016, 44, 6335-6349.

(37) Mao, Y.; Yu, C.; Hsieh, T.-S.; Nitiss, J. L.; Liu, A. A.; Wang, H.; Liu, L. F. Mutations of human topoisomerase II alpha affecting multidrug resistance and sensitivity. Biochemistry 1999, 38, 1079310800.

(38) Sayers, J. R.; Eckstein, F. Properties of overexpressed phage T5 D15 exonuclease. Similarities with Escherichia coli DNA polymerase I 5'-3' exonuclease. J. Biol. Chem. 1990, 265, 18311-18317.

(39) Liu, Y.; Hua, Z.-C.; Leng, F. DNA Supercoiling Measurement in Bacteria. Methods Mol. Biol. 2018, 1703, 63-73.

(40) Jude, K. M.; Hartland, A.; Berger, J. M. Real-time detection of DNA topological changes with a fluorescently labeled cruciform. Nucleic Acids Res. 2013, 41, No. e133.

(41) Zhu, C.-X.; Roche, C. J.; Tse-Dinh, Y.-C. Effect of Mg(II) binding on the structure and activity of Escherichia coli DNA topoisomerase I. J. Biol. Chem. 1997, 272, 16206-16210.

(42) Perry, K.; Mondragón, A. Biochemical characterization of an invariant histidine involved in Escherichia coli DNA topoisomerase I catalysis. J. Biol. Chem. 2002, 277, 13237-13245.

(43) Bhaduri, T.; Bagui, T. K.; Sikder, D.; Nagaraja, V. DNA topoisomerase I from Mycobacterium smegmatis. An enzyme with distinct features. J. Biol. Chem. 1998, 273, 13925-13932.

(44) Ahmed, W.; Menon, S.; Godbole, A. A.; Karthik, P. V. D. N. B.; Nagaraja, V. Conditional silencing of topoisomerase I gene of Mycobacterium tuberculosis validates its essentiality for cell survival. FEMS Microbiol. Lett. 2014, 353, 116-123.

(45) Sassetti, C. M.; Boyd, D. H.; Rubin, E. J. Genes required for mycobacterial growth defined by high density mutagenesis. Mol. Microbiol. 2003, 48, 77-84.
(46) Ravishankar, S.; Ambady, A.; Awasthy, D.; Mudugal, N. V.; Menasinakai, S.; Jatheendranath, S.; Guptha, S.; Sharma, S.; Balakrishnan, G.; Nandishaiah, R.; Ramachandran, V.; Eyermann, C. J.; Reck, F.; Rudrapatna, S.; Sambandamurthy, V. K.; Sharma, U. K. Genetic and chemical validation identifies Mycobacterium tuberculosis topoisomerase I as an attractive anti-tubercular target. Tuberculosis 2015, 95, 589-598.

(47) Jain, P.; Nagaraja, V. Indispensable, functionally complementing $\mathrm{N}$ and $\mathrm{C}$-terminal domains constitute site-specific topoisomerase I. J. Mol. Biol. 2006, 357, 1409-1421.

(48) Shuman, S.; Golder, M.; Moss, B. Characterization of vaccinia virus DNA topoisomerase I expressed in Escherichia coli. J. Biol. Chem. 1988, 263, 16401-16407.

(49) Perry, K.; Hwang, Y.; Bushman, F. D.; Van Duyne, G. D. Structural basis for specificity in the poxvirus topoisomerase. Mol. Cell 2006, 23, 343-354.

(50) Pommier, Y. Topoisomerase I inhibitors: camptothecins and beyond. Nat. Rev. Cancer 2006, 6, 789-802.

(51) Martino, E.; Della Volpe, S.; Terribile, E.; Benetti, E.; Sakaj, M.; Centamore, A.; Sala, A.; Collina, S. The long story of camptothecin: From traditional medicine to drugs. Bioorg. Med. Chem. Lett. 2017, 27, 701-707.

(52) King, I. F.; Yandava, C. N.; Mabb, A. M.; Hsiao, J. S.; Huang, H.-S.; Pearson, B. L.; Calabrese, J. M.; Starmer, J.; Parker, J. S.; Magnuson, T.; Chamberlain, S. J.; Philpot, B. D.; Zylka, M. J. Topoisomerases facilitate transcription of long genes linked to autism. Nature 2013, 501, 58-62.

(53) Rialdi, A.; Campisi, L.; Zhao, N.; Lagda, A. C.; Pietzsch, C.; Ho, J. S. Y.; Martinez-Gil, L.; Fenouil, R.; Chen, X.; Edwards, M.; Metreveli, G.; Jordan, S.; Peralta, Z.; Munoz-Fontela, C.; Bouvier, N.; Merad, M.; Jin, J.; Weirauch, M.; Heinz, S.; Benner, C.; van Bakel, H.; Basler, C.; Garcia-Sastre, A.; Bukreyev, A.; Marazzi, I. Topoisomerase 1 inhibition suppresses inflammatory genes and protects from death by inflammation. Science 2016, 352, aad7993.

(54) Gellert, M.; Mizuuchi, K.; O’Dea, M. H.; Nash, H. A. DNA gyrase: an enzyme that introduces superhelical turns into DNA. Proc. Natl. Acad. Sci. U.S.A. 1976, 73, 3872-3876.

(55) Maxwell, A. DNA gyrase as a drug target. Trends Microbiol. 1997, 5, 102-109.

(56) Baba, T.; Ara, T.; Hasegawa, M.; Takai, Y.; Okumura, Y.; Baba, M.; Datsenko, K. A.; Tomita, M.; Wanner, B. L.; Mori, H. Construction of Escherichia coli K-12 in-frame, single-gene knockout mutants: the Keio collection. Mol. Syst. Biol. 2006, 2, 2006.0008.

(57) Hammonds, T. R.; Foster, S. R.; Maxwell, A. Increased sensitivity to quinolone antibacterials can be engineered in human topoisomerase IIalpha by selective mutagenesis. J. Mol. Biol. 2000, 300, 481-491.

(58) Sugino, A.; Cozzarelli, N. R. The intrinsic ATPase of DNA gyrase. J. Biol. Chem. 1980, 255, 6299-6306.

(59) Maxwell, A.; Gellert, M. The DNA dependence of the ATPase activity of DNA gyrase. J. Biol. Chem. 1984, 259, 14472-14480.

(60) Fernández-Sierra, M.; Shao, Q.; Fountain, C.; Finzi, L.; Dunlap, D. E. coli Gyrase Fails to Negatively Supercoil DiaminopurineSubstituted DNA. J. Mol. Biol. 2015, 427, 2305-2318.

(61) Sugino, A.; Higgins, N. P.; Brown, P. O.; Peebles, C. L.; Cozzarelli, N. R. Energy coupling in DNA gyrase and the mechanism of action of novobiocin. Proc. Natl. Acad. Sci. U.S.A. 1978, 75, 48384842.

(62) Lang, A. J.; Mirski, S. E. L.; Cummings, H. J.; Yu, Q.; Gerlach, J. H.; Cole, S. P. C. Structural organization of the human TOP2A and TOP2B genes. Gene 1998, 221, 255-266.

(63) Cobb, J.; Miyaike, M.; Kikuchi, A.; Handel, M. A. Meiotic events at the centromeric heterochromatin: histone $\mathrm{H} 3$ phosphorylation, topoisomerase II alpha localization and chromosome condensation. Chromosoma 1999, 108, 412-425.

(64) Chen, W.; Qiu, J.; Shen, Y. M. Topoisomerase IIalpha, rather than IIbeta, is a promising target in development of anti-cancer drugs. Drug Discoveries Ther. 2012, 6, 230-237. 
(65) Hammonds, T. R.; Maxwell, A. The DNA dependence of the ATPase activity of human DNA topoisomerase IIalpha. J. Biol. Chem. 1997, 272, 32696-32703.

(66) Osheroff, N.; Shelton, E. R.; Brutlag, D. L. DNA topoisomerase II from Drosophila melanogaster. Relaxation of supercoiled DNA. J. Biol. Chem. 1983, 258, 9536-9543.

(67) Halligan, B. D.; Edwards, K. A.; Liu, L. F. Purification and characterization of a type II DNA topoisomerase from bovine calf thymus. J. Biol. Chem. 1985, 260, 2475-2482.

(68) Vaughn, J.; Huang, S.; Wessel, I.; Sorensen, T. K.; Hsieh, T.; Jensen, L. H.; Jensen, P. B.; Sehested, M.; Nitiss, J. L. Stability of the topoisomerase II closed clamp conformation may influence DNAstimulated ATP hydrolysis. J. Biol. Chem. 2005, 280, 11920-11929.

(69) Tiwari, P. B.; Annamalai, T.; Cheng, B.; Narula, G.; Wang, X.; Tse-Dinh, Y.-C.; He, J.; Darici, Y. A surface plasmon resonance study of the intermolecular interaction between Escherichia coli topoisomerase I and $\mathrm{pBAD} /$ Thio supercoiled plasmid DNA. Biochem. Biophys. Res. Commun. 2014, 445, 445-450.

(70) Szafran, M. J.; Strick, T.; Strzałka, A.; Zakrzewska-Czerwińska, J.; Jakimowicz, D. A highly processive topoisomerase I: studies at the single-molecule level. Nucleic Acids Res. 2014, 42, 7935-7946. 